\title{
Rare causes of scoliosis and spine deformity: experience and particular features
}

\author{
Konstantinos C Soultanis*1, Alexandros H Payatakes ${ }^{2,3}$, \\ Vasilios T Chouliaras², Georgios C Mandellos², Nikolaos E Pyrovolou, \\ Fani M Pliarchopoulou ${ }^{4}$ and Panayotis N Soucacos ${ }^{1}$
}

\begin{abstract}
Address: ${ }^{1} 1$ st Department of Orthopaedic Surgery, School of Medicine, University of Athens, "Attikon" Hospital, Rimini 1 Haidari 12462, Athens, Greece, ${ }^{2}$ Department of Orthopaedic Surgery, School of Medicine, University of Ioannina, Panepistemiou Avenue, Ioannina, 45 110, Greece, ${ }^{3}$ Department of Surgery, Division of Orthopaedic Surgery, Duke University Medical Center, Durham, NC 27710, USA and ${ }^{4} 4$ th Department of Internal Medicine, School of Medicine, University of Athens, "Attikon" Hospital, Rimini 1 Haidari 12462, Athens, Greece

Email: Konstantinos C Soultanis* - ksoultanis@otenet.gr; Alexandros H Payatakes - apayatakes@hotmail.com;

Vasilios T Chouliaras - vhoulio@yahoo.gr; Georgios C Mandellos - gmandellos@yahoo.co.uk; Nikolaos E Pyrovolou - nikpyr@otenet.gr; Fani M Pliarchopoulou - kpliarc@otenet.gr; Panayotis N Soucacos - soukakos@panafone.grt

* Corresponding author
\end{abstract}

Published: 23 October 2007

Scoliosis 2007, 2:15 doi:10.1186/1748-7/61-2-15
Received: 23 March 2007

Accepted: 23 October 2007

This article is available from: http://www.scoliosisjournal.com/content/2/I//5

(c) 2007 Soultanis et al; licensee BioMed Central Ltd.

This is an Open Access article distributed under the terms of the Creative Commons Attribution License (http://creativecommons.org/licenses/by/2.0), which permits unrestricted use, distribution, and reproduction in any medium, provided the original work is properly cited.

\section{Retraction}

The authors are retracting this article at the request of one of the patients. Consent to publish was obtained but subsequently withdrawn. The article is no longer available online in order to protect the privacy of the individual. The authors apologize to readers for the inconvenience.
Publish with Bio Med Central and every scientist can read your work free of charge

"BioMed Central will be the most significant development for disseminating the results of biomedical research in our lifetime. "

Sir Paul Nurse, Cancer Research UK

Your research papers will be:

- available free of charge to the entire biomedical community

- peer reviewed and published immediately upon acceptance

- cited in PubMed and archived on PubMed Central

- yours - you keep the copyright

Submit your manuscript here:

http://www.biomedcentral.com/info/publishing_adv.asp
Biomedcentral 